\title{
Effect of some essential oils on oxidative stability of peanut oil
}

\author{
By Damián M. Maestri, Julio A. Zygadlo, Alicia L. Lamarque, \\ Diana O. Labuckas and Carlos A. Guzmán \\ Cátedra de Química Orgánica, Facultad de Ciencias Exactas, Físicas y Naturales. \\ Universidad Nacional de Córdoba. Avda. Vélez Sarsfield 299, 5000 Córdoba, Argentina
}

\section{RESUMEN}

Efecto de algunos aceites esenciales sobre la estabilidad oxidativa del aceite de maní.

Se evaluó el efecto antioxidante de los aceites esenciales de Origanum majorana, Rosmarinus officinalis, Myrcianthes cisplatensis, Acantholippia seriphioides, Eucalyptus cinerea y Tagetes filifolia en el aceite de maní a $60^{\circ} \mathrm{C}$. Las concentraciones de aceites esenciales utilizadas fueron 0.02 y $0.1 \%$. Los aceites esenciales de O. majorana, A. seriphioides y $T$. filifolia exhibieron una pronunciada actividad antioxidante seguidos por $R$. officinalis, E. cinerea y $M$. cisplatensis en orden decreciente.

PALABRAS-CLAVE: Aceite esencial - Aceite de mani Actividad antioxidante.

\section{SUMMARY}

Effect of some essential oils on oxidative stability of peanut oil.

Antioxidative effect of essential oils from Origanum majorana, Rosmarinus officinalis, Myrcianthes cisplatensis, Acantholippia seriphioides, Eucalyptus cinerea and Tagetes filifolia, was tested in peanut oil at $60^{\circ} \mathrm{C}$. The concentrations of essential oils used were 0.02 and $0.1 \%$. Origanum majorana, A. seriphioides and T. filifolia essential oils exhibited a pronounced antioxidative activity, followed by $R$. officinalis, E. cinerea and $M$. cisplatensis in a decreasing order.

KEY-WORDS: Antioxidant activity - Essential oil - Peanut oil.

\section{INTRODUCTION}

Antioxidants are major ingredients that protect the quality of oils by retarding oxidation. Currently, BHA (butylated hydroxyanisole), BHT (butylated hydroxytoluene), PG (propyl gallate) and TBHQ (tertbutylhydroquinone) are used as antioxidants in lipidcontaining foods (Astill et al., 1975; Branen, 1975). However, natural antioxidants are suggested as alternatives to BHA and BHT (Witting, 1975; Huang et al., 1994; Koga and Terao, 1994). Therefore, extraction, characterization, and utilization of natural antioxidants is desired.

The antioxidant properties of certain herbs and spices have been known for a long time (Chipault et al., 1956; Economou et al., 1991; Svoboda and Deans, 1992; Kim et al., 1994). Essential oils from a number of plants are known to possess antioxidant activities, including thyme, sage, mint, marjoram, clove, etc. (Tsimidou and Boskou, 1994).

The present study was undertaken to determine and compare the antioxidant properties of essential oils of some aromatic plants. These plants were: Origanum majorana, Rosmarinus officinalis, Myrcianthes cisplatensis, Acantholippia seriphioides, Eucalyptus cinerea and Tagetes filifolia.

\section{MATERIALS AND METHODS}

\subsection{Obtainment of essential oils}

Aromatic plants were collected from different sites: Origanum majorana $L$. and Rosmarinus officinalis $L$. from Río Segundo (Córdoba), Myrcianthes cisplatensis Cam. and Eucalyptus cinerea F. von Mueller from Tucumán, Tagetes filifolia Lag. from Alta Gracia (Córdoba) and Acantholippia seriphioides Mold. from San Juan. Origanum majorana and Rosmarinus officinalis were cultivated materials.

Fresh plant material was steam-distilled; a period of $2 \mathrm{~h}$. proved to be sufficient for complete extraction. The essential oils were stored in amber glass vials with teflon-lined caps and kept in the dark at $2-6^{\circ} \mathrm{C}$ until analyzed (Verghese, 1986).

\subsection{Sample preparation}

A calculated quantity of the essential oils was added to peanut oil and the mixture was stirred for 10 min. at $25^{\circ} \mathrm{C}$. The samples were placed in open beakers at $60^{\circ} \mathrm{C}$ in the dark. A control sample was 
prepared, under the same conditions, without adding any antioxidant (Zygadlo et al., 1995).

The peroxide value (PV) was determined by the method Cd8-53 of the Association of Official Analytical Chemists (AOAC, 1980).

\subsection{Quantitation and identification of essential oils using GC-MS}

Analyses were carried out on a Hewlett-Packard 5890 gas chromatograph fitted with a $30 \mathrm{~m} \times 0.25 \mathrm{~m}$ fused silica SE-54 capillary column which was temperature programmed as follws: $70^{\circ} \mathrm{C}(5 \mathrm{~min})$ and $70^{\circ}-220^{\circ} \mathrm{C}\left(4^{\circ} \mathrm{C} / \mathrm{min}\right)$. Nitrogen was used as carrier gas at a flow rate of $1 \mathrm{~mL} / \mathrm{min}$. The chromatograph was coupled to a HP5971A mass selective detector at 70 $\mathrm{eV}$. The identification of components was based on comparison of their mass spectra with those of the authentic standards in combination with retention time and data reported in the literature (Verghese, 1986).

\section{RESULTS AND DISCUSSION}

The major components of the essential oils are presented in Table I. The data of peanut oil measured as $\mathrm{PV}$ at $60^{\circ} \mathrm{C}$ after the addition of essential oils are plotted in Fig. 1. The reproducibility of PVs was determined by using five samples each time during twelve days. BHT was used, for comparison, at concentrations no greater than $0.02 \%$, because that is usually the highest level of its use in oils, fats and lipidcontaining foods (Branen, 1975). Essential oil components are volatile and would have volatilized from the samples, making it impossible to determine their true effectiveness as antioxidants. To discard this possibility, samples of peanut oil with 0.02 and $0.1 \%$ essential oil concentrations were placed into closed, transparent glass bottles and stored at $60^{\circ} \mathrm{C}$ in the dark. No significant differences were found with respect to samples in open beakers; therefore, these data were not shown.

It was evident from Fig. 1 that the PV of the control oil was significantly higher than PVs of all treatments after 12 days of storage. The treatments containing 0.02 and $0.1 \%$ essential oils were not significantly different from each other until day 4, when the treatment containing $0.02 \%$ essential oils was lower in PVs than the other treatment. In both treatments, the induction periods (considered as the number of days needed for the PV of the sample to become 20 meq $\mathrm{O}_{2} / \mathrm{kg}$ oil) of peanut oil containing essential oils or BHT were longer than the induction period of the control. At a concentration of $0.02 \%$, some essential oils ( $T$. filifolia, $A$. seriphioides and $O$. majorana) reached the end of their induction period by the end of the storage test.

Phenolic compounds, which occur widely in plants, were considered for a long period of time to be antioxidants (Pratt and Hudson, 1990; Papadopoulos and Boskou, 1991; Tian and White, 1994). Origanum majorana and $A$. seriphioides essential oils, rich in phenolic compounds, protected oil appreciably at concentrations of $0.02 \%$. Deighton et al. (1993) suggested that stable free radicals are formed readily in the essential oils rich in phenolic compounds and that these free radicals may act to control lipid peroxidation.

The most predominant oil component of $R$. officinalis, $M$. cisplatensis and $E$. cinerea was 1,8 cineole, while in T. filifolia anethole and methyl chavicol were the major compounds (Table I). These essential oils at concentrations of $0.02 \%$ in peanut oil, showed protection action under the conditions used (Fig. 1).

Table I

Essential oil compositions. Major components

\begin{tabular}{|c|c|}
\hline Species & (\%) Compounds \\
\hline Origanum majorana $L$. & $\begin{array}{l}\text { a-pinene (1.0), p-cymene (4.7), thymol (5.0) and carvacrol } \\
\text { (77.0), a-terpinene (4.8) }\end{array}$ \\
\hline Rosmarinus officinalis $L$. & $\begin{array}{l}\text { a-pinene (12.0), camphene (4.0), } \beta \text {-pinene ( } 8.0) \text {, limonene } \\
(1.0), 1,8 \text { cineole }(57.0) \text {, p-cymene }(2.5) \text {, camphor }(6.7) \text { borneol } \\
(3.0)\end{array}$ \\
\hline Myrcianthes cisplatensis Camb. & $\begin{array}{l}\text { a-pinene (10.0), camphene (1.0), } \beta \text {-pinene (3.0), limonene } \\
(2.3), 1,8 \text { cineole (43.0), p-cymene (3.0), camphor (2.0) borneol } \\
(5.0)\end{array}$ \\
\hline Eucalyptus cinerea F. von Mueller & $\begin{array}{l}\text { a-pinene (5.0), } \beta \text {-pinene (10.0), limonene (5.0), 1,8 cineole } \\
(70.0), p \text {-cymene }(5.0) \text {. }\end{array}$ \\
\hline Acantholippia seriphioides Mold. & $\begin{array}{l}\text { a-pinene }(2.0) \text {, piperitone }(3.0) \text {, p-cymene }(4.0) \text {, thymol }(55.0) \text {, } \\
\text { carvacrol }(10.0) \text {. }\end{array}$ \\
\hline Tagetes filifolia Lag. & anethole (70.0), methyl chavicol (25.2) \\
\hline
\end{tabular}



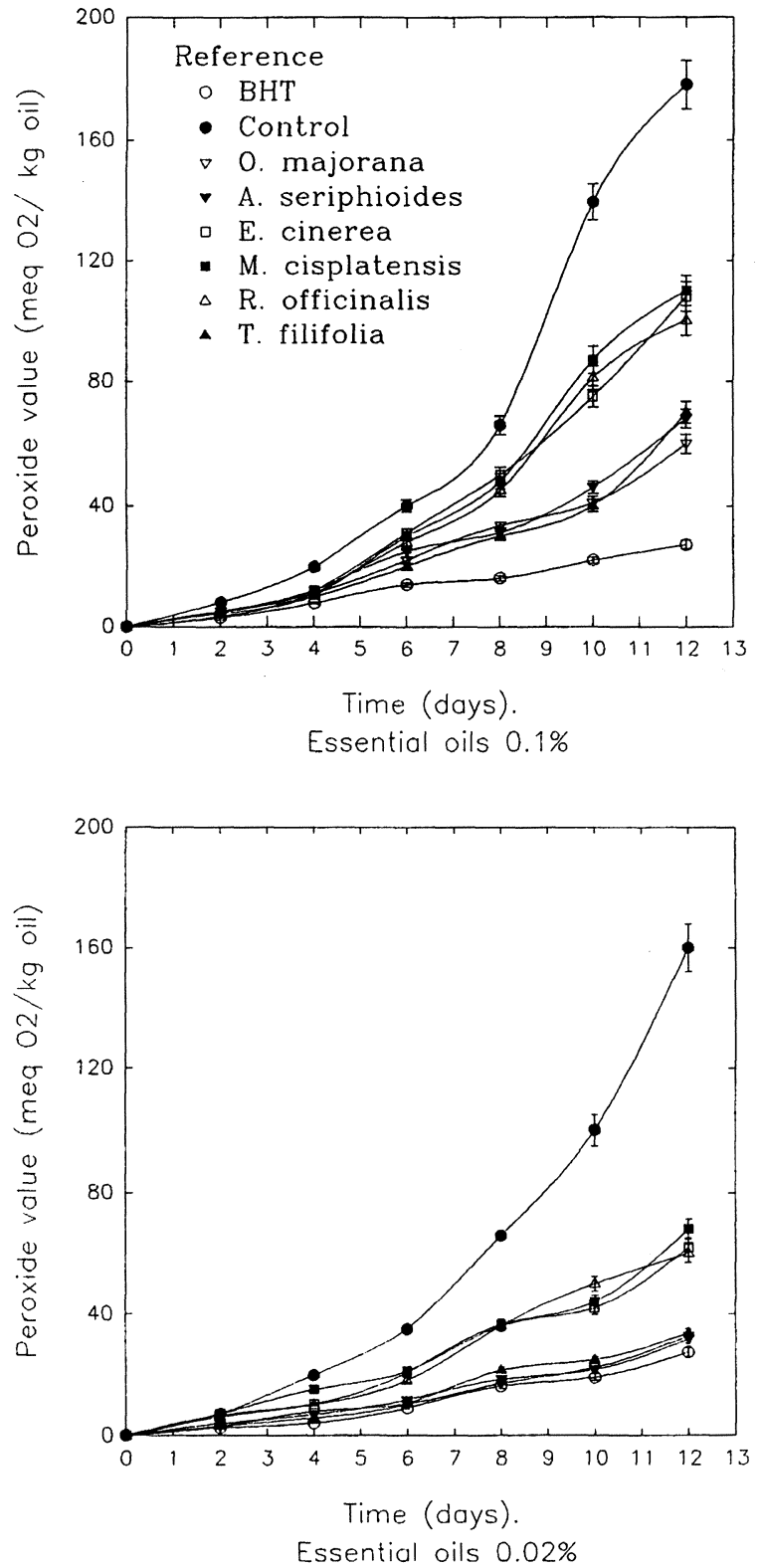

Figure 1

Autoxidation of peanut oil showing different deterioration rates

Previous works on antioxidant activity assays have demostrated that the phenomenon is concentration depended (Huang et al., 1994; Tian and White, 1994; Hemeda and Klein, 1990; Wu et al., 1994). In the present work, the concentration of essential oils for maximum antioxidant activity was $0.02 \%$. As the concentration of essential oils in peanut oil increased, the antioxidant activity decreased (Fig. 1). These results agree with those reported by Pokorny (1987) and Terao and Matsushita (1986), who found that as the concentration of antioxidant was increased beyond a certain limit, the antioxidant efficiency tended to decreased.
Some of the plants employed in this study ( $O$. majorana, $R$. officinalis) are widely used as spices or teas in popular medicine (Trease and Evans, 1988; Tsimidou and Boskou, 1994), whereas E. cinerea and $T$. filifolia are sources for essential oils and other valuable constituents (Abburrá et al., 1990, Maestri et al., 1991). The ability of these essential oils to inhibit oxidation, and the present health concerns about synthetic antioxidants indicates the possibility that these compounds could be alternative antioxidants after all toxicological data have been determined.

\section{ACKNOWLEDGEMENTS}

This study was supported by grants of CONICET, CONICOR and SECyT-UNC (Argentina).

\section{REFERENCES}

Abburrá, R. E., Zygadlo, J. A., Grosso, N. R. y C. A. Guzmán (1990). - «Estudio del aceite esencial de T. filifolia (Asteraceae) como potencial productor de estragol y anetol».- An. Asoc. Quím. Argent. 78 (3), 153-153.

AOAC (1980). - "Official Methods of Analysis of the Association of Official Analytical Chemists".- Horwitz, W. (Ed.). Washington D.C., USA.

Astill, B. D., Terhaar, C. J., Krasavage, W. J., Wolf, G. L., Roudabush R. L. and Fassett D. W. (1975). - «Safety evaluation and biochemical behavior of monotertiarybutylhydroquinone».- J. Am. Oil Chem. Soc. 52, 53-58.

Branen, A. L. (1975). - «Toxicology and biochemistry of butylated hydroxyanisol and butylated hydroxytoluene».J. Am. Oil Chem. Soc. 52, 59-67.

Chipault, J. R., Mizuno, G. R. and Lundberg, W. O. (1956). - «The antioxidant properties of spices in foods».- Food Technol. 10, 209-215.

Deighton, N., Glidewell, S. M., Deans, S. G. and Goodman, B. A. (1993). - «Identification by EPR spectroscopy of carvacrol and thymol as the major source of free radicals in the oxidation of plant essential oils".- J. Sci. Food Agric. 63, 221-225.

Economou, K. D., Oreopoulou, V. and Thomopoulos, C. D. (1991). - «Antioxidant activity of some plant extracts of the family Labiatae».- J. Am. Oil Chem. Soc. 68 (2), 109-113.

Hemeda, H. M. and Klein, B. P. (1990). - «Effects of naturally ocurring antioxidants on peroxidase activity of vegetable extracts".- J. Food Sci. 55 (1), 184-185.

Huang, S., Frankel, E. N. and German, J. B. (1994). - «Antioxidant activity of $\alpha$-tocopherols and $\gamma$-tocopherols in bulk oils and in oil-in-water emulsions".- J. Agric. Food Chem. 42, 2108-2111.

Kim, S. Y., Kim, J. H., Kim, S. K., Oh, M. J. and Jung, M. Y. (1994). - «Antioxidant activities of selected oriental herb extracts".- J. Am Oil Chem. Soc 71 (6), 633-639.

Koga, T. and Terao, J. (1994). - «Antioxidant activity of a novel phosphatidyl derivative of vitamine $E$ in lard and its model system».- J. Agric. Food Chem. 42, 1291-1294. 
Maestri, D. M., Zygadlo, J. A., Grosso, N. R., Abburrá, R. E. y Guzmán C. A. (1991). - "Composición del aceite esencial en poblaciones argentinas de $T$. filifolia Lag. (Compositae)".- Anales de Biología 17, 133-136.

Papadopoulos, G. and Boskou, D. (1991). -«Antioxidant effect of natural phenols on olive oil».- J. Am. Oil Chem. Soc. 68 (9), 669-671.

Pokorny, J. (1987). - «Major factors affecting autoxidation of lipids» in «Autoxidation of saturated lipids», pp. 141-206.H. Chan (Ed.).- Academic Press, London.

Pratt, D. E. and Hudson, B. J. F. (1990). - «Natural antioxidants not exploited commercially" in "Food antioxidants", pp. 171-192.- B. J. F. Hudson (Ed.).Elsevier, Amsterdam.

Svoboda, K. P. and Deans, S. G. (1992). - «A study of the variability of rosemary and sage and their volatile oils on the British market: their antioxidative properties".- Flav. and Frag. J. 7, 81-87.

Terao, J. and Matsushita, S. (1986). - «The peroxidizing effects of $a$-tocopherol on autoxidation of methyl linoleate in bulk phase".- Lipids 21, 255-260.

Tian, L. L. and White, P. J. (1994). - «Antioxidant activity of oat extract in soybean and cottonseed oils".- J. Am. Oil Chem. Soc. 71 (10), 1079-1086.

Trease, G. E. and Evans, W. C. (1988). -«Tratado de Farmacognosia».- 12nd Ed. -Editorial Interamericana, México D. F.

Tsimidou, M. and Boskou, D. (1994). - «Antioxidant activity of essential oils from the plants of the Lamiaceae family" in «Spices, herbs and edible fungi» Vol. 34, pp. 273-284. G. Charalambous (Ed.).- Elsevier, Amsterdam.

Verghese, J. (1986). -«On essential oils».- Synthite Industrial Chemicals Private Ltd., India.

Witting, L. A. (1975). - «Vitamin E as a food additive».- J. Am. Oil Chem. Soc. 52, 64-68.

Wu, K., Zhang, W., Addis, P. B., Epley R. J., Salih, A. M. and Lehrfeld, J. (1994). - «Antioxidant properties of wild rice».- J. Agric. Food Chem. 42, 34-37.

Zygadlo, J. A., Lamarque, A. L., Maestri, D. M. y Grosso, N. R. (1995). - «Empleo de aceites esenciales como antioxidantes naturales».- Grasas y Aceites 46 (4-5), 285-288.

Recibido: Junio 1996

Aceptado: Septiembre 1996 